\title{
Kudoa spp. (Myxozoa) infection in musculature of Plagioscion squamosissimus (Sciaenidae) in the Amazon region, Brazil
}

\author{
Infecção por Kudoa spp. (Myxozoa) na musculatura de Plagioscion squamosissimus (Sciaenidae) \\ da região amazônica, Brasil
}

Joyce Cardim de Oliveira ${ }^{1,2}$; Michele Velasco ${ }^{2,3} ;$ Patrícia de Fátima Sacco dos Santos ${ }^{2,4}$; José Mauro Viana Silva ${ }^{1,2}$; Sérgio Carmona de São Clementé5 ${ }^{5}$ Edilson Matos ${ }^{2 *}$

\begin{abstract}
'Programa de Pós-graduação em Aquicultura e Recursos Aquáticos Tropicais, Instituto Sócio-Ambiental e dos Recursos Hídricos, Universidade Federal Rural da Amazônia - UFRA, Belém, PA, Brasil

${ }^{2}$ Laboratório de Pesquisa Carlos Azevedo - LPCA, Universidade Federal Rural da Amazônia - UFRA, Belém, PA, Brasil

${ }^{3}$ Programa de Pós-graduação em Biologia de Agentes Infecciosos e Parasitários, Instituto de Ciências Biológicas, Universidade Federal do Pará - UFPA, Belém, PA, Brasil

${ }^{4}$ Faculdade Integrada Ipiranga, Belém, PA, Brasil

${ }^{5}$ Departamento de Tecnologia e Inspeção de Alimentos, Universidade Federal Fluminense - UFF, Niterói, RJ, Brasil
\end{abstract}

Received Novermber 13, 2014

Accepted February 19, 2015

\begin{abstract}
Ninety specimens of Plagioscion squamosissimus captured using fishing tackle in the Outeiro district, state of Pará, were examined. Fish were placed in plastic bags containing water, under conditions of artificial aeration, and transported live to the Carlos Azevedo Research Laboratory (LPCA), in Belém, Pará. They were anesthetized, euthanized and necropsied; small fragments of the epaxial and hypaxial muscles were removed for examination of fresh histological sections by means of optical microscopy. In 100\% of the specimens analyzed, parasitic pseudocysts were seen to be interspersed within and between the skeletal muscle. These contained pseudoquadrate and/or star-shaped spores that presented four valves and four polar capsules, which were identified from their morphology as belonging to the genus Kudoa. This is the first report of Kudoa in P. squamosissimus in the Amazon region, Pará, Brazil.
\end{abstract}

Keywords: White fish, histology, amazonian region, Myxozoan, parasite, Plagioscion squamosissimus.

\section{Resumo}

Foram observados 90 exemplares de P. squamosissimus, capturados com apetrechos de pesca no distrito de Outeiro, estado do Pará. Os animais foram acondicionados em sacos plásticos com água do habitat e aeraçáo artificial, transportados vivos até o Laboratório de Pesquisa Carlos Azevedo (LPCA), em Belém-PA. Foram anestesiados, eutanasiados e necropsiados; pequenos fragmentos da musculatura epi e hipoaxial foram retirados para observaçáo, a fresco e para histologia em microscopia de luz (ML). Em 100\% dos exemplares analisados, foi observada a presença de pseudocistos parasitários entremeados, dentro e entre as fibras musculares estriadas esqueléticas, onde observou-se a presença de esporos de formato pseudoquadrado e/ou estrelado, com quatro valvas e quatro cápsulas polares, sendo identificados pela sua morfologia como pertencentes ao gênero Kudoa. Este é o primeiro relato de Kudoa em P. squamosissimus na Amazônia, Pará, Brasil.

Palavras-chave: Pescada branca, histologia, região amazônica, myxosporídios, parasito, Plagioscion squamosissimus.

\section{Introduction}

The Amazon region has an abundance and diversity of fish and is very important for commercial and artisanal fishing. The Outeiro district of Belém is located on the island of Caratateua, which is situated $18 \mathrm{~km}$ from the main urban area of Belém (the

*Corresponding author: Edilson Rodrigues Matos. Avenida Presidente Tancredo Neves, 2501, Bairro Montese, CEP 66077-530, Belém, PA, Brasil. e-mail: edilson.matos9@gmail.com state capital of Pará) and is connected directly to the Icoaraci district. The island is surrounded by the murky, muddy freshwater of the Guajará bay (PEREIRA, 2001). Because of the influence of the bay, a wide variety of fish is available on the island, thereby allowing local subsistence and artisanal fishing. Among the variety of fish species is Plagioscion squamosissimus Heckel, 1840, which is popularly known as hake and accounts for one of the largest productions of artisanal and industrial fishing (BARTHEM, 1985; BOEGER \& KRITSKY, 2003; VIANA et al., 2006). This species 
has benthopelagic habits and is carnivorous (BARTHEM, 1985; BOEGER \& KRITSKY, 2003; SANTOS et al., 2006; VIANA et al., 2006). In Pará, this species has high commercial value, both in freshwater fishing in the estuary and also possibly due to the changes in salinity in the dry season (BARTHEM, 1985).

Interest in studying parasites in fish has increased over recent years because of the consequences and economic losses produced by their presence, as well as the hazards that they present to human health, with the possibility of food and/or allergic poisoning. Parasites of the phylum Myxozoa, which includes myxosporidians, have been the subject of many studies recently. The locations of aquatic myxosporidians in their hosts are varied, and they are found in nearly all tissues and organs. The species of this genus are mostly histozoic (intercellular or intracellular) and are often found in the somatic musculature of their hosts. They can also be found in the heart, intestines, gills, brain, kidneys, gallbladder and blood (LOM \& DYKOVÁ, 2006; MACIEL et al., 2011).

Most species of myxosporidians have pathogenic effects on their hosts. For example, the genus Kudoa currently consists of more than 95 species (EIRAS et al., 2014) and causes lesions to the somatic musculature of fish. This may have a significant economic impact through softening of the flesh, with or without formation of macroscopic pseudocysts, which gives rise to postmortem myoliquefaction (ANDRADA et al., 2005). This muscle lysis effect is caused by the action of proteases that the parasites produce and use to soften the muscles of the host in order to promote their own development (ANDRADA et al., 2005). This effect compromises the acceptance of these fish among consumers. Furthermore, there is evidence that consumption of fish that have been infected by Kudoa may cause allergic symptoms (MARTÍNEZ DE VELASCO et al., 2007; GRABNER et al., 2012; KAWAI et al., 2012). The present study describes a infection in muscle tissue of Plagioscion squamosissimus fish caught in the Amazon Region.

\section{Materials and Methods}

Ninety specimens of the freshwater fish $P$. squamosissimus Heckel, 1840 (Teleostei, Perciformes), Brazilian common name "pescada branca", i.e. "white fish", were collected from the Amazonian estuarine region of Outeiro ( $1^{\circ} 14^{\prime} \mathrm{S}$; $\left.48^{\circ} 26^{\prime} \mathrm{W}\right)$ near the city of Belém. The mean total length of the fish was $12.28 \pm 3.67 \mathrm{~cm}$ (range: 7.5-18.30) and their mean weight was $25.14 \pm 18.48 \mathrm{~g}$ (range: 6.12-61.8). They were lightly anesthetized using MS 222 Sigma (Sabdoz Laboratories) diluted in freshwater and after euthanize samples of infected epaxial and hypaxial muscles were taken for optical and electron microscopy studies. For optical microscopy, small fragments $(0.5 \mathrm{~cm})$ of parasitized tissue from the palate of the fish were fixed in Davidson solution (neutral buffered formalin, glacial acetic acid, 95\% ethyl alcohol and distilled water) for $24 \mathrm{~h}$ and were then processed and stained with hematoxylin-eosin (HE), May-Grunwald-Giemsa and Ziehl-Neelsen (LUNA, 1968). The stained sections were documented using a Zeiss Primo Star optical microscope and Zeiss Axio Cam ERc 5s microscope camera, with micrometrics imaging software. Some fragments containing tissue cysts were analyzed using a differential interference contrast
(DIC) microscope (Nomarski). Measurements on the spores were made in micrometers $(\mu \mathrm{m})$, with minimum and maximum values in parentheses. The dimensions were expressed as means \pm standard deviations. To calculate the statistical data, the BioStat 5.0 software was used (AYRES et al., 2007). Parasite prevalence was analyzed according to Bush et al. (1997). The measurements of the spores were made in accordance to Lom \& Dyková (1992), under 1000X magnification.

\section{Results and Discussion}

In fresh preparations of fragments of muscle tissue viewed under an optical microscope, pseudocysts were seen within and between the muscle fibers. When this material was squashed between the slide and cover slip, large numbers of spores of different shapes and sizes were observed (Figure 1). The rectangular or pseudoquadrate format and/or star shape, with four valves and four polar capsules (Figures 2 and 3), was identified from its morphology as belonging to the genus Kudoa. The taxonomic classification was as follows:

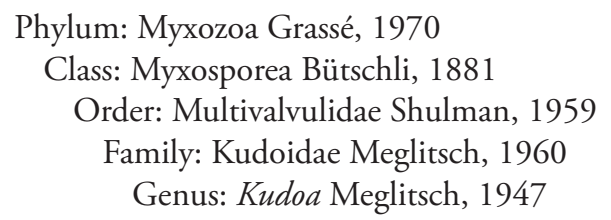

The information on the morphological data of the parasite and on the site of infection is corroborated by Heckmann (2012); Moran et al. (1999); Lom \& Dyková (1992), who reported that members of the genus Kudoa infect muscle tissues of their hosts and can present starry, square or rounded square shape in apical view.

Some studies on other host species have already recorded spores of stellate Kudoa format infecting the somatic musculature, like Kudoa histolytica Pérard, 1928; Kudoa cruciformum Matsumoto, 1954; Kudoa kabatai Shulman and Kovaleva, 1979; Kudoa bengalensis Sarkar and Mazumder, 1983; Kudoa mirabilis Naidenova and Gaevskaya, 1991; Kudoa cynoglossi Obiekezie and Lick, 1994; and Kudoa miniauriculata Whitaker et al., 1996; and also in pseudoquadrate format: Kudoa funduli Hahn, 1915; Kudoa clupeidae Hahn, 1917; Kudoa crumena Iversen and Van Meter, 1967; Kudoa alliaria Shulman and Kovaleva, 1979; Kudoa amamiensis Egusa and Nakajima, 1980; Kudoa caudata Kovaleva and Gaevskaya, 1983; and Kudoa leiostomi Dyková et al., 1994 (MORAN et al., 1999).

The infection site observed was limited to the skeletal muscles of the host (P. squamosissimus), and pseudocysts could not be viewed macroscopically in any infected animal. According to Abdel-Ghaffar et al. (2012), most of the genus Kudoa form macroscopic pseudocysts in muscles and cause economic problems with regard to sale of infected fish. On the other hand, like in the results from the present study, little or no inflammatory reaction has been found associated with parasitosis (ANDRADA et al., 2005; CASAL et al., 2008; BURGER \& ADLARD, 2010; HEINIGER \& ADLARD, 2012; GRABNER et al., 2012; HEINIGER et al., 2013). According to Grabner et al. (2012), Kudoa species were found in the muscle tissue of Paralichthys olivaceus, but no cyst formation or myoliquefaction was visible. On the other hand, myoliquefaction was found in Paralichthys orbignyanus parasitized by Myxobolus sp. (EIRAS et al., 2007). In Trichiurus lepturus, parasitic cysts were 

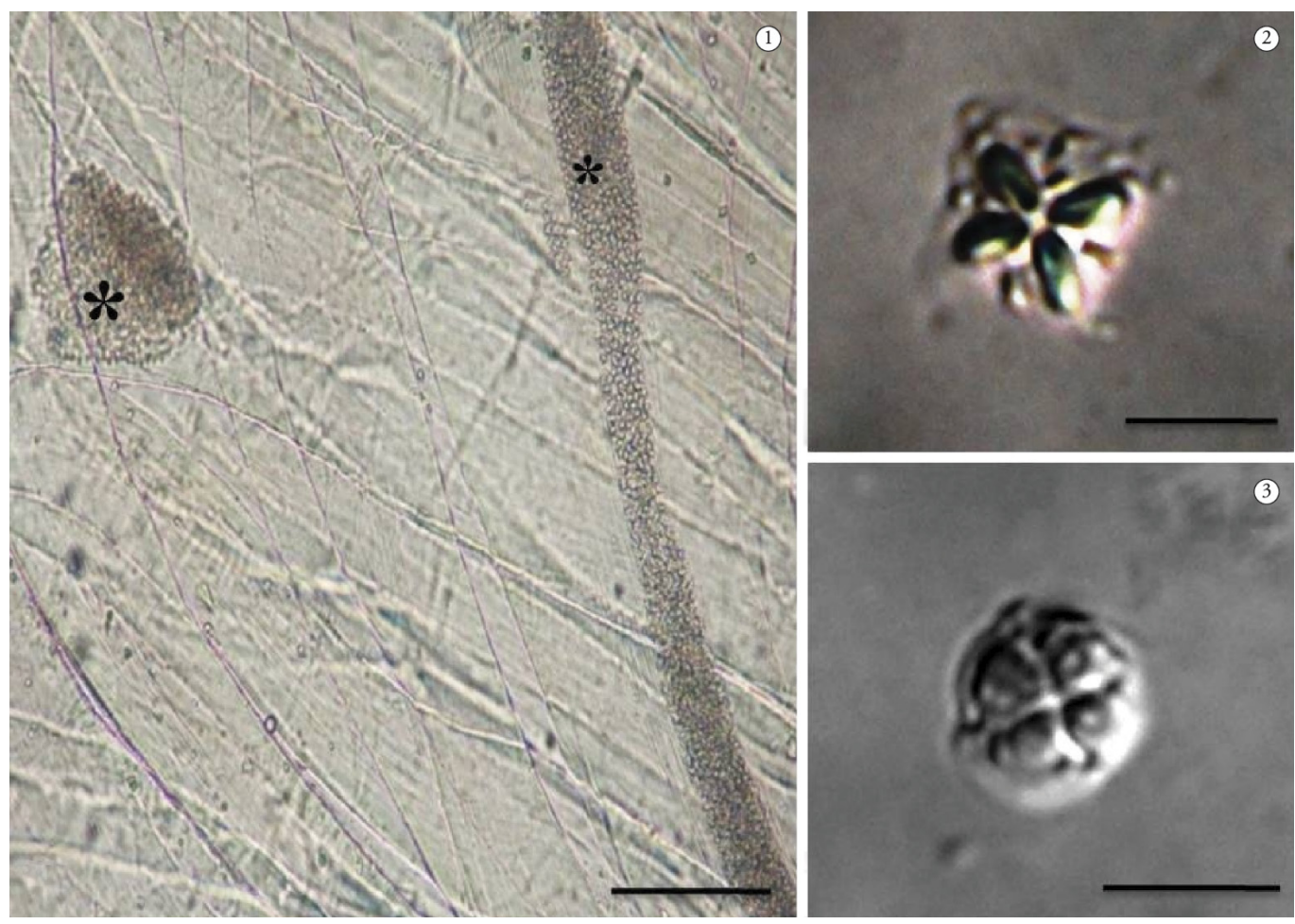

Figures 1-3. Optical micrographs: 1. Cysts of Kudoa spp. $\left({ }^{*}\right)$ in fresh muscle of P. squamosissimus Bar= $100 \mu$ m. Spores of Kudoa spp. in DIC: 2. stellate in format; 3. Pseudoquadrade in format. $\mathrm{Bar}=5 \mu \mathrm{m}$.

found in somatic muscle fibers, but with no inflammatory reaction (ANDRADA et al., 2005). In Aequidens plagiozonatus, Kudoa aequidens was reported with ultrastructural data; this was first reported in Brazilian aquatic fauna in the subopercular muscles, thus emphasizing that no direct inflammatory responses were found in the fibers but, rather, free spores that had disintegrated between myofibrils, which indicated that muscle liquefaction was associated with presence of spores (CASAL et al., 2008).

The biometric data on the spores of Kudoa spp. in apical view and stellate format comprised length of $9.70 \pm 0.14 \mu \mathrm{m}$ and width of $9.33 \pm 0.25 \mu \mathrm{m}$. The four polar capsules in piriform shape consisted of two larger and two smaller capsules, with lengths of $4.05 \pm 0.07 \mu \mathrm{m}$ and $3.63 \pm 0.18 \mu \mathrm{m}$ and widths of $1.28 \pm 0.32 \mu \mathrm{m}$ and $1.15 \pm 0.14 \mu \mathrm{m}$, respectively. Spores of pseudoquadrate square format presented length of $5.63 \pm 0.18 \mu \mathrm{m}$ and width of $5.60 \pm 0.07 \mu \mathrm{m}$; the four polar capsules were equal in size and had a piriform shape, with length of $1.75 \pm 0.24 \mu \mathrm{m}$ and width of $0.98 \pm 0.06 \mu \mathrm{m}$. Table 1 shows measurement data relating to spore sizes, shapes, lengths and widths of some polar Kudoa species capsules, in comparison with the data of the present study.

From comparisons of morphological species of the genus Kudoa, it could be seen that the length, width and polar capsule measurements of the Kudoa species of the present study differed from the species previously studied, thus giving evidence that there must be two new species. Previously, in fish from the Amazon River, only K. aequidens had been described by Casal et al. (2008) in Aequidens plagiozonatus (common name: cará pixuna).
Examination of the histological sections revealed that the parasite Kudoa spp. was presented within and between the muscle fibers (Figure 4-7), with 100\% prevalence. The extent of the damage and the fate of the infected muscle fibers shows that it is possible that full replacement of mature spores may occur, within and between skeletal muscle fibers, thus causing changes to the swimming behavior of the fish and making them more vulnerable to predators. This was also found by Dyková et al. (2009), who observed that the muscle fibers infected with $K$. inornata were completely replaced by spores.

Since presence of Kudoa spores in the fish host can cause lesions in its muscles, this disease has a significant economic impact because of postmortem myoliquefaction. This muscle lysis effect comes from the action of proteases, thereby leaving the muscle of the host softened (ANDRADA et al., 2005) and compromising the acceptance of the fish among consumers. Furthermore, there is evidence that consumption of fish infected with Kudoa may cause allergy symptoms or food poisoning (MARTÍNEZ DE VELASCO et al., 2007; GRABNER et al., 2012; KAWAI et al., 2012).

The observations under the microscope in the present study provide the first confirmation that the presence of infection in the musculature of P. squamosissimus is related to parasitism by two different spores of the genus Kudoa. There is a high possibility that these two new species are treatable, but analyses using transmission electron microscopy and molecular biology are necessary in order to determine the species. Studies of this nature are of great relevance, since parasitism by Kudoa may damage the muscles of the host, 
Table 1. Spore measurements (in $\mu \mathrm{m}$ ) of Kudoa sp. and other Kudoa spp.

\begin{tabular}{|c|c|c|c|c|c|c|c|c|}
\hline \multirow{2}{*}{ Species / author } & \multirow{2}{*}{ Host } & \multicolumn{3}{|c|}{ Spore } & \multicolumn{4}{|c|}{ Polar capsules } \\
\hline & & Spore form & $\mathrm{C}$ & $\mathbf{L}$ & $\mathrm{C}$ & L & com & $\operatorname{lm}$ \\
\hline $\begin{array}{l}\text { Kudoa sp. } \\
\text { (This study) }\end{array}$ & $\begin{array}{l}\text { Plagioscion } \\
\text { squamosissimus }\end{array}$ & Stellate & $\begin{array}{l}9.70 \pm 0.14 \\
(9.6-9.85)\end{array}$ & $\begin{array}{l}9.33 \pm 0.25 \\
(9.15-9.5)\end{array}$ & $\begin{array}{l}4.05 \pm 0.07^{*} \\
(4.00-4.10)\end{array}$ & $\begin{array}{c}1.28 \pm 0.32^{* *} \\
(1.05-1.5)\end{array}$ & $\begin{array}{l}3.63 \pm 0.18 \\
(3.5-3.75)\end{array}$ & $\begin{array}{c}1.15 \pm 0.14 \\
(1.05-1.25)\end{array}$ \\
\hline- & - & $\begin{array}{l}\text { Square / } \\
\text { Pseudoquadrade }\end{array}$ & $\begin{array}{l}5.63 \pm 0.18 \\
(5.6-5.85)\end{array}$ & $\begin{array}{l}5.60 \pm 0.07 \\
(5.40-5.60)\end{array}$ & $\begin{array}{l}1.75 \pm 0.24 \\
(1.4-2.00)\end{array}$ & $\begin{array}{l}0.98 \pm 0.06 \\
(0.90-1,1)\end{array}$ & - & - \\
\hline $\begin{array}{l}K . \text { lunata } \\
\text { (Lom \& Dyková, 1988) }\end{array}$ & Arnoglossus laterna & Stellate & 5.3 & 10.0 & 2.5 & 1.5 & - & - \\
\hline $\begin{array}{l}\text { K. aequidens sp. n./ } \\
\text { (Casal et al., 2008) }\end{array}$ & $\begin{array}{l}\text { Aequidens } \\
\text { plagiozonatus }\end{array}$ & Pseudoquadrade & 3.2 & 6.8 & 2.15 & 1.25 & - & - \\
\hline $\begin{array}{l}\text { K. inornata sp. n./ } \\
\text { (Dyková et al., 2009) }\end{array}$ & $\begin{array}{l}\text { Cynoscion } \\
\text { nebulosus }\end{array}$ & Pseudoquadrade & 5.4 & 5.9 & 2.7 & - & - & - \\
\hline $\begin{array}{l}\text { K. thunni n. sp./ } \\
\text { (Matsukane et al., 2011) }\end{array}$ & Thunnus alalunga & Pseudoquadrade & $\begin{array}{c}6.5 \\
(6.4-6.6)\end{array}$ & $\begin{array}{c}9.5 \\
(9.2-9.9)\end{array}$ & $\begin{array}{c}2.5 \\
(2.2-2.9)\end{array}$ & $\begin{array}{c}2.1 \\
(1.9-2.2)\end{array}$ & - & - \\
\hline $\begin{array}{l}\text { K. leptacanthae n. sp./ } \\
\text { (Heiniger \& Adlard, } \\
\text { 2012) }\end{array}$ & $\begin{array}{l}\text { Zoramia } \\
\text { leptacantha }\end{array}$ & Pseudoquadrade & - & 8.3 & 2.8 & 1.3 & - & - \\
\hline $\begin{array}{l}\text { K. ogawai n. sp./ } \\
\text { (Yokoyama et al., 2012) }\end{array}$ & $\begin{array}{l}\text { Hyperoglyphe } \\
\text { japonica }\end{array}$ & Pseudoquadrade & $\begin{array}{c}8.93 \\
(8.3-9.6)\end{array}$ & $\begin{array}{c}13.29 \\
(12.0- \\
14.2)\end{array}$ & $\begin{array}{c}2.45 \\
(1.9-3.2)\end{array}$ & $\begin{array}{c}2.48 \\
(1.7-3.0)\end{array}$ & - & - \\
\hline $\begin{array}{l}\text { K. lemniscati n. sp./ } \\
\text { (Miller \& Adlard, 2012) }\end{array}$ & $\begin{array}{l}\text { Lutjanus } \\
\text { lemniscatus }\end{array}$ & Pseudoquadrade & - & $\begin{array}{c}15.7 \pm 0.6 \\
(14.1- \\
16.6)\end{array}$ & $\begin{array}{c}4.2 \pm 0.4 \\
(3.7-5.1)\end{array}$ & $\begin{array}{c}2.3 \pm 0.2 \\
(1.9-2.6)\end{array}$ & - & - \\
\hline $\begin{array}{l}\text { K. azevedoil } \\
\text { (Mansour et al., 2013) }\end{array}$ & $\begin{array}{l}\text { Trachurus } \\
\text { trachurus }\end{array}$ & Pseudoquadrade & $3.5 \pm 0.41$ & $\begin{array}{l}4.55 \pm 0.44 \\
(4-5.2)\end{array}$ & $\begin{array}{c}1.5 \pm 0.22 \\
(1.5-2)\end{array}$ & $\begin{array}{c}0.75 \pm 0.14 \\
(0.5-1)\end{array}$ & - & - \\
\hline
\end{tabular}

C: Length: L: Width. ${ }^{*}$ Length capsule larger. ${ }^{* *}$ Width capsule larger. com - Capsule lowest length. lm - Capsule width smaller.
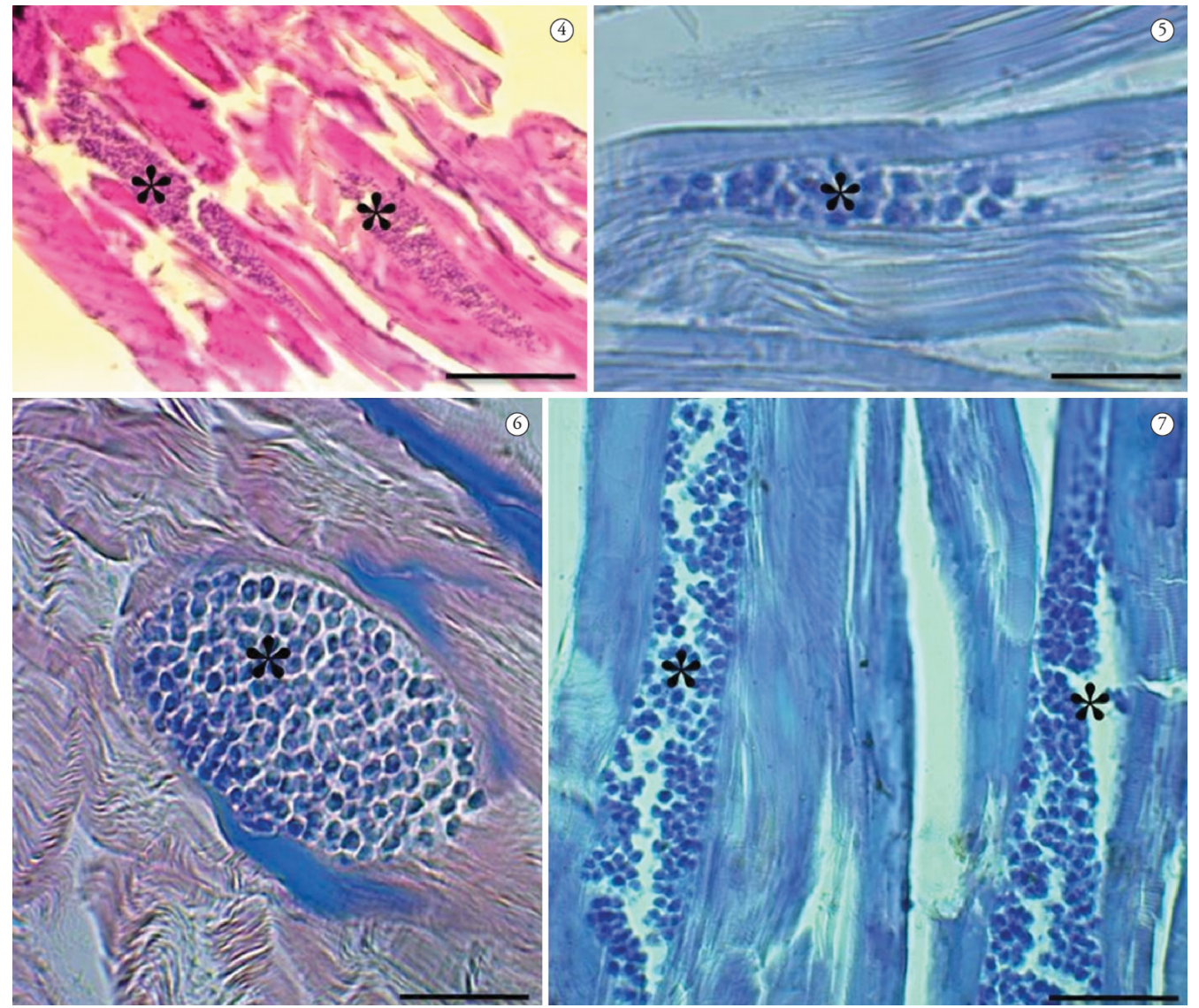

Figure 4-7. Optical micrographs: Cysts of Kudoa spp. parasitizing muscle fibers $\left(^{*}\right)$ P. squamosissimus. 4 - Staining with hematoxylin-eosin, 5 - Staining in Ziehl-Neelsen, 6 and 7 - Staining in May Grunwald-Giemsa. Bar $=5 \mu \mathrm{m}$. 
which is considered to be the finest area of the fish, thus causing commercial losses.

\section{Acknowledgements}

We are grateful to CNPq, CAPES (colleger PPG AqRAT-UFRA), Bank Santander, ICMBIO-SISBIO IBAMA (license 27119-1), FAPESPA.

\section{References}

Abdel-Ghaffar F, Morsy K, Mehlhorn H, Bashtar AR, Shazly MA, Saad $\mathrm{AH}$, et al. First report of Kudoa species (Myxozoa: Kudoidae) infecting the spotted coral grouper Plectropomus maculates from the Red Sea. A light and ultrastructural study. Parasitol Res 2012; 111(4): 1579-1585. http://dx.doi.org/10.1007/s00436-012-3011-x. PMid:22740296

Andrada CDG, Tortelly R, Nogueira PP, Andrade CL, Lima FC. Infecção por Kudoa Meglitsch, 1947 (Myxozoa: Multivalvulida) em musculatura esquelética de espada Trichiurus lepturus L. (Teleostei: Trichiuridae). Parasitol latinoam 2005; 60(3-4): 150-153.

Ayres M, Ayres-Junior M, Ayres DL, Santos AS, Ayres LL. Bioestat 5.0 aplicaçôes estatísticas nas áreas das ciências bi-médicas. Belém: IDSM; 2007.

Barthem RB. Ocorrência, distribuição e biologia dos peixes da Baía de Marajó, Estuário Amazônico. Bol Mus Para Emilio Goeldi 1985; 2(1): 49-69.

Boeger WAB, Kritsky DC. Parasites, Fossils and Geologic History: Historical Biogeography of the South American Freshwater Croakers, Plagioscion spp. (Teleostei, Sciaenidae). Zool Scr 2003; 32(1): 3-11. http:// dx.doi.org/10.1046/j.1463-6409.2003.00109.x.

Burger MAA, Adlard RD. Four new species of Kudoa Meglitsch, 1947 (Myxosporea: Multivalvulida) from Australia with recommendations for species descriptions in the Kudoidae. Parasitology 2010; 137(5): 793814. http://dx.doi.org/10.1017/S0031182009991557. PMid:20025820

Bush AO, Lafferty KD, Lotz JM, Shostak AW. Parasitology meets ecology on its own terms: Margolis et al. revisited. J Parasitol 1997; 83(4): 575583. http://dx.doi.org/10.2307/3284227. PMid:9267395

Casal G, Matos E, Matos P, Azevedo C. Ultrastructural Description of a New Myxosporean Parasite Kudoa aequidens sp. n. (Myxozoa, Myxosporea), found in the Sub-Opercular Musculature of Aequidens plagiozonatus (Teleostei) from the Amazon River. Acta Protozool 2008; 47: 135-141.

Dyková I, Buron I, Fiala I, Roumillat WA. Kudoa inornata sp. n. (Myxosporea: Multivalvulida) from the skeletal muscles of Cynoscion nebulosus (Teleostei: Sciaenidae). Folia Parasitol 2009; 56(2): 91-98. http://dx.doi.org/10.14411/fp.2009.014. PMid:19606785

Eiras JC, Júnior JP, Sampaio LA, Robaldo R, Abreu PC. Myxobolus sp. can cause in vivo myoliquefaction in the host Paralichthys orbignyanus (Osteichthyes, Paralichthydae). Dis Aquat Organ 2007; 77(3): 255-258. http://dx.doi.org/10.3354/dao01852. PMid:18062475

Eiras JC, Saraiva A, Cruz C. Synopsis of the species of Kudoa Meglitsch, 1947 (Myxozoa: Myxosporea: Multivalvulida). Syst Parasitol 2014; 87(2): 153-180. http://dx.doi.org/10.1007/s11230-013-9461-4. PMid:24474038

Grabner DS, Yokoyama H, Shirakashi S, Kinami R. Diagnostic PCR assays to detect and differentiate Kudoa septempunctata, K. thyrsites and $K$. lateolabracis (Myxozoa, Multivalvulida) in muscle tissue of olive flounder (Paralichthys olivaceus). Aquaculture 2012; 338-341: 36-40. http://dx.doi.org/10.1016/j.aquaculture.2012.01.022.

Heckmann RA. Histopathology and fine structure of two myxosporidans, Kudoa clupeidae and Henneguya sebasta and a microsporidian glugea infecting fishes from the California, USA coast, histozoic parasites. Proc Parasitol 2012; 54: 1-25.

Heiniger H, Adlard RD. Host specificity and local infection dynamics of Kudoa leptacanthae n. sp. (Multivalvulida: Kudoidae) from the pericardial cavity of two Zoramia spp. (Perciformes: Apogonidae) at Lizard Island lagoon, Queensland, Australia. Parasitol Int 2012; 61(4): 697-706. http:// dx.doi.org/10.1016/j.parint.2012.08.001. PMid:22922116

Heiniger H, Cribb TH, Adlard RD. Intra-specific variation of Kudoa spp. (Myxosporea: Multivalvulida) from apogonid fishes (Perciformes), including the description of two new species, $K$. cheilodipteri $\mathrm{n}$. sp. and K. cookii n. sp., from Australian waters. Syst Parasitol 2013; 84(3): 193215. http://dx.doi.org/10.1007/s11230-012-9400-9. PMid:23404757

Kawai T, Sekizuka T, Yahata Y, Kuroda M, Kumeda Y, Iijima Y, et al. Identification of Kudoa septempunctata as the causative agent of novel food poisoning outbreaks in Japan by consumption of Paralichthys olivaceus in raw fish. Clin Infect Dis 2012; 54(8): 1046-1052. http:// dx.doi.org/10.1093/cid/cir1040. PMid:22281845

Lom J, Dyková I. Myxozoan genera: definition and notes on taxonomy, life-cycle terminology and pathogenic species. Folia Parasitol (Praha) 2006; 53(1): 1-36. http://dx.doi.org/10.14411/fp.2006.001. PMid:16696428

Lom J, Dyková I. Development in aquaculture and fisheries science. Amsterdam: Elsevier; 1992. 315 p. vol. 26. Protozoan Parasites of Fishes.

Lom J, Dyková I. Sporogenesis and spore structure in Kudoa lunata (Myxosporea, Multivalvulida). Parasitol Res 1988; 74(6): 521-530. http:// dx.doi.org/10.1007/BF00531629. PMid:3194365

Luna LG. Manual of histologic staining methods of the armed forces institute of pathology. 3rd ed. New York: MacGraw-Hill; 1968.

Maciel PO, Affonso EG, Boijink CL, Tavares-Dias M, Inoue LAKA. Myxobolus sp. (Myxozoa) in the circulating blood of Colossoma macropomum (Osteichthyes, Characidae). Rev Bras Parasitol Vet 2011; 20(1): 82-84. http://dx.doi.org/10.1590/S1984-29612011000100018. PMid:21439240

Mansour L, Thabet A, Chourabi K, Harrath AH, Gtari M, Al Omar SY, et al. Kudoa azevedoi n. sp. (Myxozoa, Multivalvulida) from the oocytes of the Atlantic horse mackerel Trachurus trachurus (Perciformes, Carangidae) in Tunisian coasts. Parasitol Res 2013; 112(4): 1737-1747. http://dx.doi.org/10.1007/s00436-013-3332-4. PMid:23435961

Martínez de Velasco G, Rodero M, Chivato T, Cuéllar C. Seroprevalence of anti-Kudoa sp. (Myxosporea: Multivalvulida) antibodies in a Spanish population. Parasitol Res 2007; 100(6): 1205-1211. http://dx.doi. org/10.1007/s00436-006-0390-x. PMid:17177059

Matsukane Y, Sato H, Tanaka S, Kamata Y, Sugita-Konishi Y. Kudoa iwatai and two novel Kudoa spp., K. trachuri n. sp. and K. thunni n. sp. (Myxosporea: Multivalvulida), from daily consumed marine fish in western Japan. Parasitol Res 2011; 108(4): 913-926. http://dx.doi.org/10.1007/ s00436-010-2133-2. PMid:21053015

Miller TL, Adlard RD. Brain infecting kudoids of Australia's coral reefs, including a description of Kudoa lemniscati n. sp. (Myxosporea: Kudoidae) from Lutjanus lemniscatus (Perciformes: Lutjanidae) off Ningaloo Reef, Western Australia. Parasitol Int 2012; 61(2): 333-342. http://dx.doi. org/10.1016/j.parint.2012.01.002. PMid:22260905 
Moran JDW, Whitaker DJ, Kent ML. A review of the myxosporean genus Kudoa Meglitsch, 1947, and its impact on the international aquaculture industry and commercial fisheries. Aquaculture 1999; 172(1-2): 163-196. http://dx.doi.org/10.1016/S0044-8486(98)00437-2.

Pereira KRB. Caracterização geoquímica de sedimentos de fundo da orla de Belém - Pará [Dissertação]. Belém: Universidade Federal do Pará; 2001.

Santos GM, Ferreira EJG, Zuanon JAS. Peixes comerciais de Manaus. Manaus: IBAMA/ProVárzea; 2006.
Viana AP, Frédou T, Lucena F. Aplicaçôes de técnicas morfométricas no estudo da morfometria de pescada branca, Plagioscion squamosissimus, Heckel (1940), Perciformes, Sciaenidae, desembarcada na ilha de Mosqueiro-PA. Bol Lab Hidrobiol 2006; 19(1): 1-12.

Yokoyama H, Yanagida T, Shirakashi S. Kudoa ogawai n. sp. (Myxozoa: Multivalvulida) from the trunk muscle of Pacific barrelfish Hyperoglyphe japonica (Teleostei: Centrolophidae) in Japan. Parasitol Res 2012; 110(6): 2247-2254. http://dx.doi.org/10.1007/s00436-011-2756-y. PMid:22173453 